\title{
Fast Analysis of Taurine in Energetic Drinks by Electrospray Ionization Mass Spectrometry
}

\author{
Rodrigo R. Catharino, ${ }^{a}$ Renato Haddad, ${ }^{b}$ Helena T. Godoy, ${ }^{c}$ Marcos N. Eberlin ${ }^{b}$ and \\ Leonardo S. Santos $*$, \\ ${ }^{a}$ Department of Clinical Pathology, School of Medical Sciences, University of Campinas, \\ PO Box 6111, 13083-887 Campinas-SP, Brazil \\ ${ }^{b}$ ThoMSon Mass Spectrometry Laboratory, Institute of Chemistry, University of Campinas, \\ 13083-970 Campinas-SP, Brazil \\ 'Food Analysis Laboratory, Faculty of Food Science, University of Campinas, \\ 13083-862 Campinas-SP, Brazil \\ ${ }^{d}$ Laboratory of Asymmetric Synthesis, Instituto de Química de Recursos Naturales, Universidad de \\ Talca, PO Box 747, Talca, Chile
}

\begin{abstract}
Espectrometria de massas sequencial usando infusão direta de amostra e ionização por electrospray no modo de ions negativos foi utilizada para quantificar taurina em bebidas energéticas com alta seletividade e sensibilidade, $\mathrm{O}$ metodo é simples e rápido (menos de 2 min de corrida) e apresenta alta repetitividade e recuperação. Bebidas energéticas comerciais apresentaram quantidades de taurina em concentrações muito diferentes (menor ou maior) das quantidades declaradas.
\end{abstract}

Direct infusion electrospray ionization tandem mass spectrometry in the negative ion mode with single reaction monitoring is show to allow high selectivity and sensitivity in the quantification of taurine in energetic drinks. The method is also simple and rapid (less than 2 min run time), with high recovery and repeatability. Commercially available energetic drinks were found to contain taurine in concentrations quite different (lower or higher) from the declared amounts.

Keywords: electrospray mass spectrometry, taurine, energetic drinks, food control

\section{Introduction}

Taurine (2-aminoethane sulfonic acid, Figure 1), is a major free $\beta$-amino acid in humans. Taurine exists free in the intracellular fluid, and is widely distributed in many tissues including the myocardium, liver, skeletal muscle, brain, retina, platelets and leukocytes. Taurine is not a protein constituent and for a long time it was considered a nonessential nutrient for humans. In recent years, however, it has become clear that taurine is an important amino acid involved in a large number of metabolic processes and that it becomes essential under certain circumstances. Taurine plays also an important role in the maintenance of physiological functions. ${ }^{1-3}$ The functions of taurine include osmoregulation, ${ }^{4}$ cell membrane stabilization, ${ }^{5}$

*e-mail: 1ssantos@utalca.cl antioxidation, ${ }^{6}$ detoxification, ${ }^{3}$ neuromodulation,,${ }^{7,8}$ and brain and retinal development. ${ }^{9}$ Moreover, some pharmacological functions of taurine have also been reported against congestive heart failure, ${ }^{10}$ liver disease, ${ }^{11}$ hyperlipidemia ${ }^{12}$ and epilepsy. ${ }^{13}$<smiles>NCCS(=O)(=O)O</smiles>

Taurine

Figure 1. Taurine amino acid.

Taurine occurs naturally in food, especially in seafood and meat. The mean daily intake from omnivore diets was determined to be around $58 \mathrm{mg}$ (range from 9 to $372 \mathrm{mg}$ ) and to be low or negligible from a strict vegan diet. ${ }^{14-16}$ Taurine intake has been also estimated to be generally less than 
$200 \mathrm{mg}$ per day, even in individuals eating a high meat diet. ${ }^{15}$ There has been concern about the effects and amount of taurine intakes mainly from "energetic" drinks. ${ }^{17,18}$ Positive effects of taurine-containing drinks such as on hormonal responses which led to a higher athletic performance have been reported. ${ }^{19}$ High performance liquid chromatography (HPLC) preceded by extraction procedures has been the main approach applied to quantify taurine. ${ }^{20,21}$ Altogether, these steps are time-consuming and not so easy to automate. With the main objective to simplify and minimize the time of analysis, whereas keeping a satisfactory level of selectivity and sensitivity, we tested a direct infusion electrospray ionization tandem mass spectrometry approach to determine taurine in energetic drinks.

\section{Experimental}

Five different brands of "energetic" drinks, all of them containing taurine, were purchased from supermarkets in Brazil (São Paulo State) from January to April 2010. Three lots were analyzed, differentiated by fabrication dates for each of the five trade marks. All samples were within the validity period and without any visible damages. All determinations were conducted in triplicate.

The standard of taurine was purchased from Sigma (T-0625, 61K0127). HPLC grade methanol was purchased from Merck. The water used for sample and mobile phase preparation was purified using the Milli-Q system (Millipore). The mobile phases were filtrated by Millipore filters with $0.45 \mu \mathrm{m}$ size pores.

ESI-MS ${ }^{\mathrm{n}}$ analyses were performed on a API 2000 QTrap (Applied Biosystem) mass spectrometer. The tandem mass spectrometric (MS/MS) experiments were performed using single reaction monitoring (SRM) for the dissociation of the precursor ion of $\mathrm{m} / \mathrm{z}, 124$ to its most abundant fragment ion of $m / z 80$. The best mode of ion detection for taurine was the negative ion mode. The major conditions were as follows: scan range, $m / z 50-200$; heater temperature, $100{ }^{\circ} \mathrm{C}$; flow of the nitrogen carrier gas, $20 \mathrm{~L} \mathrm{~min}^{-1}$; sheath gas, $0.0 \mathrm{~L} \mathrm{~min}^{-1}$; curtain gas, $20 \mathrm{~L} \mathrm{~min}{ }^{-1}$; nebulizer potential, $-3500 \mathrm{~V}$; declustering potential, $-46 \mathrm{~V}$; and entrance potential, $-7 \mathrm{~V}$.

\section{Analytical methodology}

Aliquots of $100 \mu \mathrm{L}$ from the energetic drinks were quantitatively transferred to a $1.5 \mathrm{~mL}$ volumetric flask. After the homogenization, the solutions were first filtrated two times with a common filter paper and next with a Durapore membrane (HVLP 01300 Millipore) with $0.45 \mu \mathrm{m}$ size pores. Subsequently, the samples were automated injected into the ESI source of the mass spectrometer $(10 \mu \mathrm{L})$ by using an Aliance HPLC system (Waters). Taurine was eluted by an isocratic elution system using a 1:1 methanol/ water solution.

\section{Method validation: Limits of detection and quantification}

A preliminary evaluation of the limit of detection (LOD) was performed by automatic successive dilutions of taurine using an Aliance HPLC system (Waters), determining the lower detectable amount that was, approximately, two to three times the average value of noise. After determining the LOD, taurine was quantitated in samples of energetic drinks. Amounts of the standard taurine, equivalent and higher than established for LOD curves using pure standard, were added to the drink matrixes. The limit of quantification (LOQ) was considered as three times the LOD. ${ }^{22}$ The ESI(-)-MS of pure taurine (Figure 2) shows mainly the deprotonated molecule $[\mathrm{M}-\mathrm{H}]^{-}$of $\mathrm{m} / z, 124$ as well as the dimer of $m / z 249$, the trimer of $m / z, 374$ and the tetramer of $\mathrm{m} / \mathrm{z}$ 499. The ion of $\mathrm{m} / \mathrm{z} 80$ was attributed to $\mathrm{SO}_{3}{ }^{-}$formed via in-source collision-induced dissociation of $[\mathrm{M}-\mathrm{H}]^{-}$.

\section{Standard recovery}

The accuracy of the method was evaluated through recovery tests by adding taurine standard to the energetic drinks using two different concentration levels: $8.5 \mathrm{mg} / 100 \mathrm{~mL}$ and $85.0 \mathrm{mg} / 100 \mathrm{~mL}$ for $100 \mu \mathrm{L}$ of sample. All determinations were conducted in triplicate.

\section{Repeatability}

The closeness of the agreement between the results of successive measurements of the same measurand carried out under the same conditions of measurement. The repeatability was evaluated by five determinations, in triplicate, using two concentration levels of taurine in standard solutions and in energetic drinks. The repeatability conditions included the same measurement procedure, the same analyst, the same measuring instrument, used under the same conditions, the same location, and repetition over a short period of time. The repeatability was calculated following Caulcutt and Boddy. ${ }^{22}$

\section{Results and Discussion}

The direct injection ESI(-)-MS/MS method developed using flow-injection type of setup allows rapid determination of taurine, that is, within approximately $1.3 \mathrm{~min}$ after injection, with a total analysis time of $c a .2 \mathrm{~min}$. Although no pre-separation is employed, false positives are minimized 


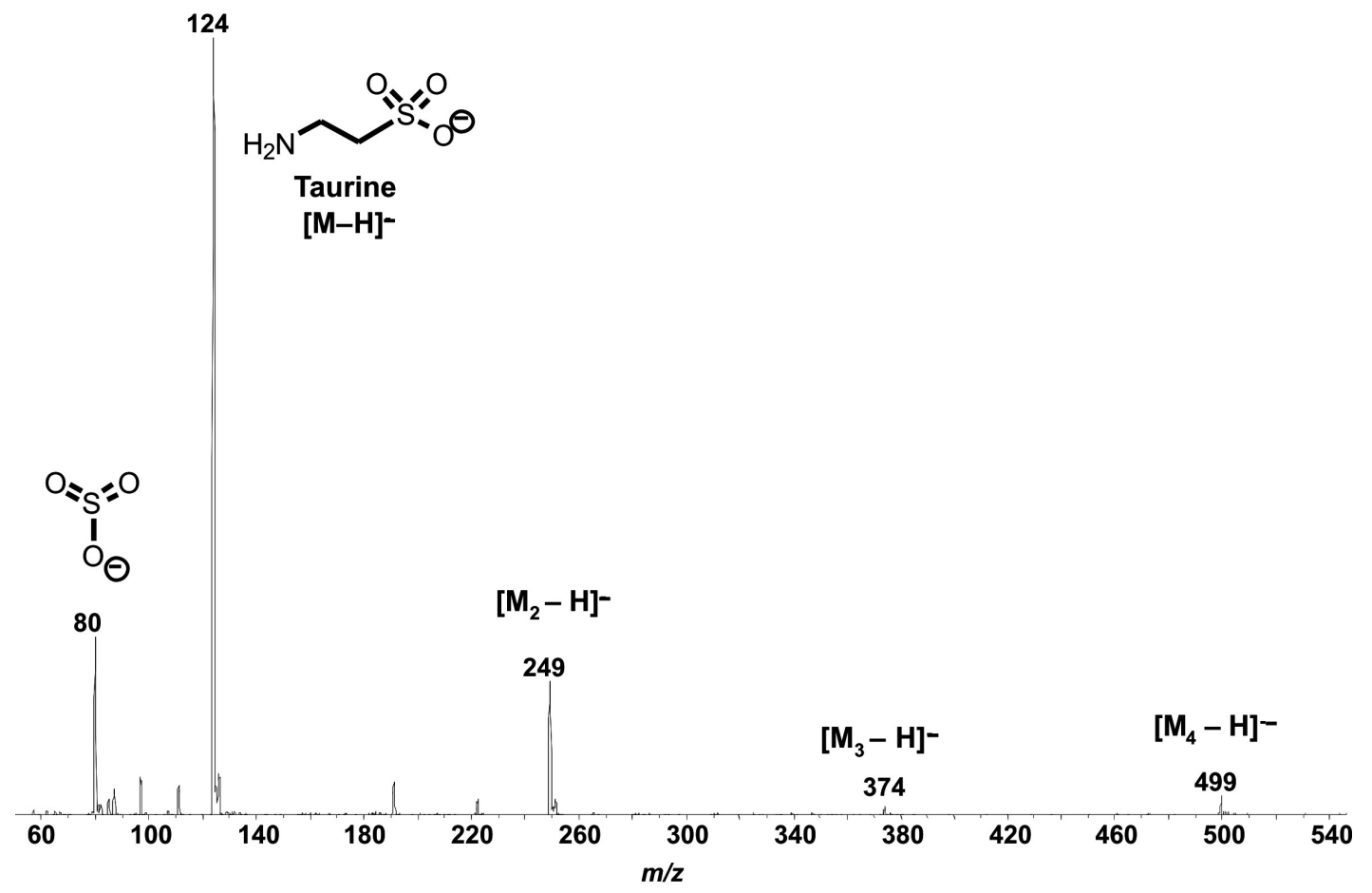

Figure 2. ESI(-)-MS of a taurine solution in $\mathrm{H}_{2} \mathrm{O}: \mathrm{MeCN}(1: 1 \mathrm{v} / \mathrm{v})$.

through the use of SRM (Figure 3 and 4) via the transition $m / z 124 \rightarrow m / z 80$. The analytical curve for taurine, outlined by external standardization, displays good linearity within the range of pre-established concentration from $10 \mathrm{mg} \mathrm{mL}^{-1}$ to $0.1 \mathrm{mg} \mathrm{mL}^{-1}$, with an excellent correlation coefficient of 0.999 (Figure 5). The analyses showed no matrix effect

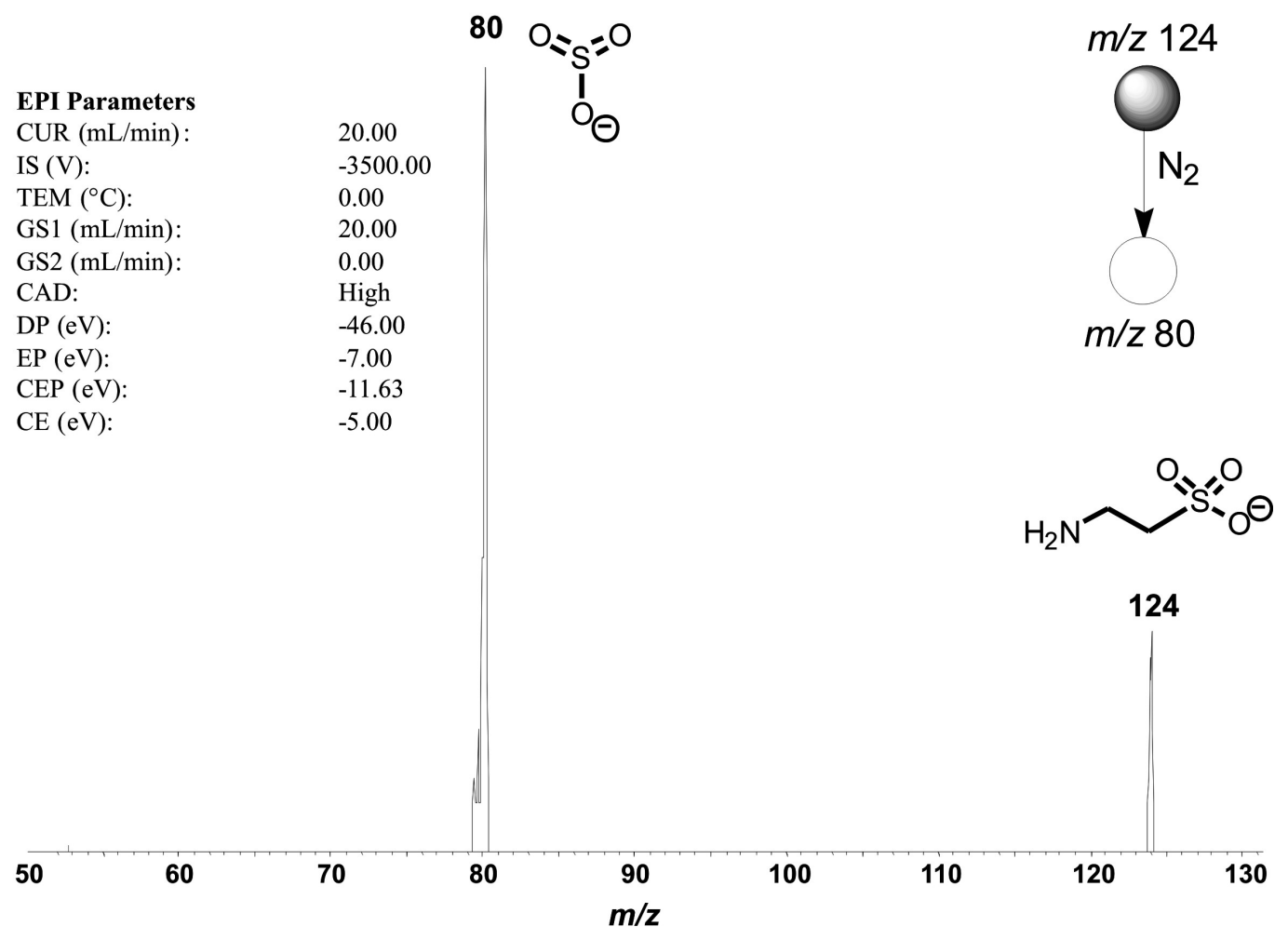

Figure 3. ESI(-)-MS/MS for deprotonated taurine of $m / z$ 124. Note major dissociation by the loss of neutral molecule of $\mathrm{C}_{2} \mathrm{H}_{6} \mathrm{~N}$ composition to form $\mathrm{SO}_{3}^{-}$of $m / 2,80$. 


$\begin{array}{ll}\text { MRM Parameters } & \\ \text { CUR }(\mathrm{mL} / \mathrm{min}): & 20.00 \\ \text { IS }(\mathrm{V}): & -3500.00 \\ \text { TEM }\left({ }^{\circ} \mathrm{C}\right): & 0.00 \\ \text { GS1 }(\mathrm{mL} / \mathrm{min}): & 20.00 \\ \text { GS2 }(\mathrm{mL} / \mathrm{min}): & 0.00 \\ \text { CAD: } & \text { High } \\ \text { DP }(\mathrm{eV}): & -46.00 \\ \text { EP }(\mathrm{eV}): & -7.00 \\ \text { CEP }(\mathrm{eV}): & -11.63 \\ \text { CE }(\mathrm{eV}): & -5.00\end{array}$

$m / z 124$

$m / z 80$
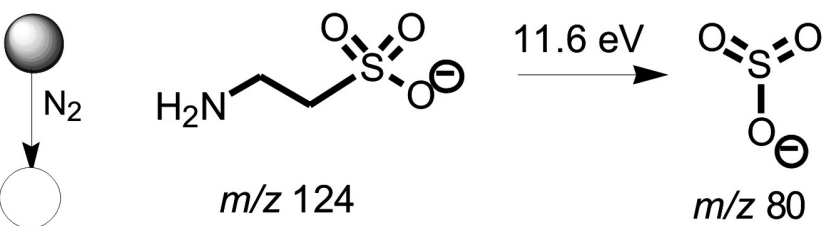

$m / z 80$

0.1

0.3

0.5

0.7

time / min

Figure 4. Cromatogram using SRM $(\mathrm{m} / z, 124 \rightarrow \mathrm{m} / \mathrm{z}, 80)$ showing the detection of taurine after $1.3 \mathrm{~min}$ of sample injection.

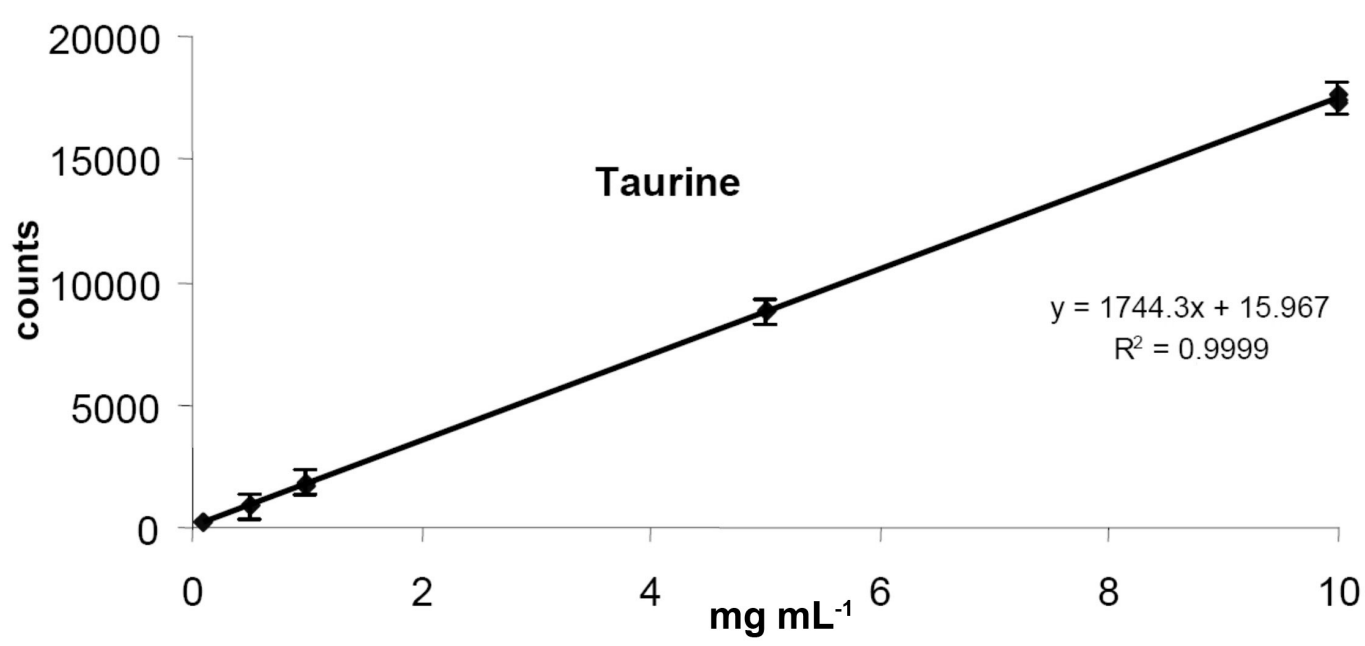

Figure 5. Analytical curve for taurine quantification in energetic drinks.

according to the use of SRM. The slope calibration curves from conventional and matrix-matched were statistically identical.

Table 1 shows the concentrations of taurine determined in several samples of energetic drinks. From the five brands of energetic drinks analyzed, three of them displayed much lower amounts of the amino acid corresponding to just 30 to $35 \%$ of the declared values. The brands RB and FH displayed amounts much higher than the ones declared, that is, $217 \%$ and $175 \%$, respectively.

\section{Methodology validation}

The LOD found for taurine from standard solutions and energetic drink samples were the same: $0.03 \mathrm{mg} \mathrm{mL}^{-1}$. The LOQ was therefore $0.1 \mathrm{mg} \mathrm{mL}^{-1}$. The recovery rates varied between $99.1-99.2 \%$ in the two levels of energetic drinks (Table 2). These values reveal a good recovery rate for levels of amino acids present in the drink. Table 3 shows the repeatability ranges found from five determinations of taurine in standard solution and energetic drinks, with 95\% 
Table 1. Quantification data of taurine in energetic drinks by ESI-MS/MS (SRM)

\begin{tabular}{|c|c|c|c|}
\hline Brand lot & ${ }^{a}$ Label $(\mathrm{mg} / 100 \mathrm{~mL})$ & ${ }^{\mathrm{b}} \mathrm{TA}(\mathrm{mg} / 100 \mathrm{~mL}), \mathrm{A} \pm \mathrm{SD}$ & ${ }^{\mathrm{c}} \mathrm{CV}(\%)$ \\
\hline $\mathrm{BU}$ & & $134 \pm 1.2$ & 0.9 \\
\hline $\mathrm{BU}$ & 400 & $128 \pm 0.9$ & 0.7 \\
\hline $\mathrm{BU}$ & & $102 \pm 1.3$ & 1.3 \\
\hline Average of BU lots & & 121.3 & \\
\hline $\mathrm{AT}$ & & $147 \pm 1.8$ & 1.2 \\
\hline AT & 400 & $140 \pm 1.5$ & 1.1 \\
\hline AT & & $128 \pm 1.3$ & 1.0 \\
\hline Average of AT lots & & 138.3 & \\
\hline $\mathrm{BB}$ & & $123 \pm 1.1$ & 0.9 \\
\hline BB & 400 & $125 \pm 1.6$ & 1.3 \\
\hline BB & & $140 \pm 1.2$ & 0.9 \\
\hline Average of BB lots & & 129.3 & \\
\hline $\mathrm{RB}$ & & $870 \pm 1.1$ & 0.1 \\
\hline $\mathrm{RB}$ & 400 & $880 \pm 1.2$ & 0.1 \\
\hline $\mathrm{RB}$ & & $850 \pm 1.4$ & 0.2 \\
\hline Average of RB lots & & 866.7 & \\
\hline $\mathrm{FH}$ & & $880 \pm 1.2$ & 0.1 \\
\hline $\mathrm{FH}$ & 400 & $870 \pm 0.9$ & 0.1 \\
\hline $\mathrm{FH}$ & & $352 \pm 1.3$ & 0.4 \\
\hline Average of FH lots & & 700.7 & \\
\hline
\end{tabular}

${ }^{\mathrm{a}}$ Concentration of taurine declared on the label; ${ }^{\mathrm{b}}$ Concentration of taurine found on the samples; ${ }^{\mathrm{c}}$ Coefficient of variation. $\mathrm{A}=\mathrm{amount} ; \mathrm{SD}=\mathrm{Standard} \mathrm{Deviation}$

Table 2. Recovery of taurine in energetic drinks

\begin{tabular}{cccc}
\hline $\begin{array}{c}\text { Concentration in sample } \\
\mathrm{mg} / 100 \mathrm{~mL}\end{array}$ & $\begin{array}{c}\text { Concentration added } \\
\mathrm{mg} / 100 \mathrm{~mL}\end{array}$ & $\begin{array}{c}\text { Concentration found } \\
\mathrm{mg} / 100 \mathrm{~mL}\end{array}$ & $\begin{array}{c}\text { Recovery } \\
(\%)\end{array}$ \\
\hline 198.2 & 8.5 & 205 & 99.1 \\
& 85 & 281.1 & 99.2 \\
\hline
\end{tabular}

Table 3. Repeatability of taurine in energetic drinks and standard solution

\begin{tabular}{|c|c|c|c|c|c|}
\hline \multicolumn{3}{|c|}{ Taurine Standard } & \multicolumn{3}{|c|}{ Energetic Drink } \\
\hline & $\mathrm{C}(\mathrm{mg} / 100 \mathrm{~mL})$ & $\mathrm{r}$ & & $\mathrm{C}(\mathrm{mg} / 100 \mathrm{~mL})$ & $\mathrm{r}$ \\
\hline \multirow{5}{*}{ Taurine } & 10.0076 & \multirow{5}{*}{0.163} & \multirow{5}{*}{ Taurine } & 100.7654 & \multirow{5}{*}{1.145} \\
\hline & 10.0831 & & & 100.2439 & \\
\hline & 10.1041 & & & 100.9072 & \\
\hline & 10.1009 & & & 100.8632 & \\
\hline & 10.1048 & & & 100.9681 & \\
\hline
\end{tabular}

$\mathrm{C}=$ concentration; $\mathrm{r}=$ repeatability.

confidence. The obtained value for five determinations in duplicate are therefore expected to vary within the limits provided by repeatability with the specified confidence.

\section{Conclusions}

Direct infusion ESI-MS/MS in the negative ion mode using SRM $(m / z, 124 \rightarrow m / z$ 80) can be applied with high confidence, speed and selectivity to quantifty taurine in energetic drinks. As observed before,$^{18}$ the present results indicate that energetic drinks often contain taurine in concentrations quite different (lower or higher) from the declared amounts.

\section{Acknowledgments}

Financial support from the São Paulo Research Foudation (FAPESP), National Council for Scientific 
and Technological Development (CNPq), and Fondecyt (1085308, L. S. S.) are gratefully acknowledged.

\section{References}

1. Chesney, R. W.; Adv. Pediatr. 1985, 32, 1.

2. Wright, C. E.; Ann. Rev. Biochem. 1986, 55, 427.

3. Huxtable, R. J.; Physiol. Rev. 1992, 72, 163.

4. Thurston, J. H.; Hauhart, R. E.; Dirgo, J. A.; Life Sci. 1980, 26 , 1561.

5. Pasantes-Morales, H.; Wright, C. E.; Gaull, G. E.; Biochem. Pharmacol. 1985, 34, 2205.

6. Nakamura, T.; Ogasawara, M.; Koyama, I.; Nemoto, M.; Yoshida, T.; Biol. Pharm. Bull. 1993, 16, 970.

7. Kuriyama, K.; Fed. Proc. 1980, 39, 2680.

8. Bernardi, N.; Acta Physiol. Pharmacol. Latinoam. 1985, 35, 153.

9. Sturman, J. A.; Ann. N. Y. Acad. Sci. 1986, 477, 196.

10. Azuma, J.; Hasegawa, H.; Awata, N.; Sawamura, A.; Harada, H.; Ogura, K.; Ohta, H.; Yamauchi, K.; Kishimoto, S.; Prog. Clin. Biol. Res. 1983, 125, 61.

11. Colombo, C.; Battezzati, P. M.; Crosignani, A.; Assaisso, M.; Ronchi, M.; Giunta, A.; Acta Univ. Carol. 1990, 36, 148.

12. Mochizuki, H.; Oda, H.; Yokogoshi, H.; J. Nutr. Biochem. 2001 , 12, 109.

13. Marchesi, G. F.; Quattrini, A.; Scarpino, O.; Dellantonio, R.; Riv. Patol. Nerv. Ment. 1975, 96, 166.

14. Rana, S. K.; Sanders, T. A. B.; Brit. J. Nutr. 1986, 56, 17.
15. Laidlaw, S. A.; Grosvenor, M.; Kopple, J. D.; J. Parent. Ent. Nutr. 1990, 14, 183.

16. Hayes, K. C.; Trautwein, E. A. In Modern Nutrition in Health and Disease. Taurine; Shils, M. E.; Olson, J. A.; Shike, M.; eds.; Lea \& Febiger: Philadelphia, PA, 1994.

17. Evaluation of the Potential Risks to Health from "Energetic Drinks": Background Information. Unpublished submission to the European Commission compiled from information submitted by Member States. CS/PLEN/ENDRINKS/1 Addendum. 2 December 1996. (data available from authors under request).

18. Scientific Documents for the Evaluation of the Harmlessness of Red Bull Energetic Drink. Unpublished submission to the European Commission by Red Bull GmbH, Austria. CS/PLEN/ ENDRINKS/2. January 1997. (data available from authors under request).

19. Geiss, K. R.; Jester, I.; Falke, W.; Hamm, M.; Wang, K. L.; Amino Acids 1994, 7, 45.

20.Yang, Z.; Zhang, P.; J. Health Res. 1998, 27, 192.

21.Aranda, M.; Morlock, G.; J. Chromatogr. A 2006, 1131, 253.

22. Caulcutt, R.; Boddy, R.; Statistic for Analytical Chemists, $1 \mathrm{st}$ ed.; Chapman \& Hall: London, 1983.

Submitted: August 18, 2010

Published online: January 25, 2011

FAPESP has sponsored the publication of this article. 